\title{
Pengaruh Penggunaan Asam Terhadap Pemisahan Logam dari Abu Layang Batubara Sebagai Bahan Dasar Sintesis Zeolit
}

\section{The Effect of Using Acid on Separation of Metals from Coal Fly Ash as Basis of Zeolite Synthesis}

\author{
Hesti Prihastuti ${ }^{1}$, Nuryoto ${ }^{\mathbf{1 , 2}}$, Anton Irawan ${ }^{1,2}$, Teguh Kurniawan ${ }^{\mathbf{1 , 2}}$ \\ ${ }^{1}$ Program Studi Magister Teknik Kimia, Pasca Sarjana, Universitas Sultan Ageng Tirtayasa \\ Jl. Raya Jakarta Km.4 Pakupatan, Serang, 42122, Indonesia \\ ${ }^{2}$ Jurusan Teknik Kimia, Fakultas Teknik, Universitas Sultan Ageng Tirtayasa \\ Jl. Jend Sudirman Km.3, Cilegon, 42435, Indonesia \\ *E-mail: teguh@untirta.ac.id
}

DOI: https://doi.org/10.26874/jkk.v4i1.72

Received: 13 Feb 2021, Revised: 30 May 2021, Accepted: 30 May 2021, Online: 31 May 2021

\begin{abstract}
Abstrak
Abu layang merupakan produk samping berupa limbah padat yang dihasilkan dari proses pembakaran batubara pada pembangkit tenaga listrik, yang mengandung sebagian besar senyawa silika $\left(\mathrm{SiO}_{2}\right)$, alumina $\left(\mathrm{Al}_{2} \mathrm{O}_{3}\right)$, dan oksida besi $\left(\mathrm{Fe}_{2} \mathrm{O}_{3}\right)$. Abu layang berpotensi digunakan sebagai bahan dasar sintesis zeolit. Adanya pengotor pada abu layang seperti $\mathrm{Fe}$ dan $\mathrm{Ca}$ akan berpengaruh terhadap tingkat kemurnian zeolit yang diperoleh. Oleh karena itu penelitian ini bertujuan untuk mempelajari pengaruh penggunaan asam klorida $(\mathrm{HCl})$ terhadap pemisahan logam $\mathrm{Fe}$ dan $\mathrm{Ca}$ dari abu layang sebagai bahan dasar sintesis zeolit. Metode yang digunakan untuk pemisahan logam $\mathrm{Fe}$ dan $\mathrm{Ca}$ menggunakan $\mathrm{HCl}$ dari abu layang adalah dengan menggunakan refluks. Pada penelitian ini, $\mathrm{HCl}$ dibuat variasi konsentrasi 4 M; $8 \mathrm{M}$; dan $12 \mathrm{M}$ dan dilakukan analisis X-Ray Fluoerescence (XRF) terhadap abu layang. Kandungan logam Fe dan Ca sebelum perlakuan asam adalah $34.28 \%$ dan 21.60\%. Berdasarkan hasil analisis XRF, abu layang dengan perlakuan asam $\mathrm{HCl} 4 \mathrm{M}, 8 \mathrm{M}$ dan $12 \mathrm{M}$ menunjukkan penurunan kandungan $\mathrm{Fe}$ menjadi 16,29\%; 14,03\%; 11,98\% dan penurunan Ca menjadi 3,59\%, 3,30\%, dan 2,96\%. Dapat disimpulkan bahwa pemisahan kandungan logam $\mathrm{Fe}$ dan Ca kadarnya semakin berkurang dari abu layang dengan semakin besar konsentrasi $\mathrm{HCl}$.
\end{abstract}

Kata kunci: abu layang; asam klorida; zeolite

\begin{abstract}
Fly ash is a by-product in the form of solid waste generated from the burning process of coal in power plants, which contains mostly silica $\left(\mathrm{SiO}_{2}\right)$, alumina $\left(\mathrm{Al}_{2} \mathrm{O}_{3}\right)$, and iron oxide $\left(\mathrm{Fe}_{2} \mathrm{O}_{3}\right)$ compounds. $\mathrm{Fly}$ ash has the potential to be used as a base for zeolite synthesis. The presence of impurities in fly ash such as $\mathrm{Fe}$ and $\mathrm{Ca}$ will affect the purity level of the zeolite obtained. Therefore, this study aims to see the effect of using hydrochloric acid $(\mathrm{HCl})$ on the separation of $\mathrm{Fe}$ and $\mathrm{Ca}$ metals from fly ash as a basic material for zeolite synthesis. The method used to separate Fe and Ca metals using HCl from fly ash is reflux. In this study, $\mathrm{HCl}$ was made with a concentration variation of $4 \mathrm{M} ; 8 \mathrm{M}$; and $12 \mathrm{M}$ and X-Ray Fluoerescence (XRF) analysis was performed on fly ash. Based on the results obtained from XRF, it showed that fly ash using $4 \mathrm{M}, 8 \mathrm{M}$ and $12 \mathrm{M} \mathrm{HCl}$ obtained Fe metal content of 16.29\%; 14.03\%; $11.98 \%$ and $\mathrm{Ca} 3.59 \%, 3.30 \%$, and 2.96\%. So it can be concluded that the separation of Fe and Ca metal content decreases from fly ash with the greater the $\mathrm{HCl}$ concentration.
\end{abstract}

Key words: fly ash; hydrochloric acid; zeolite 


\section{Pendahuluan}

Pada saat ini sudah banyak industri yang menggunakan bahan batu bara sebagai bahan bakar pada pembangkit tenaga listrik, karena harganya cukup murah dan keberadaannya berlimpah di Indonesia. Kondisi sangat menguntungkan bagi industri. Penggunaan batu bara dalam Pembangkit Listrik Tenaga Uap (PLTU) dan industri lainnya akan menghasilkan limbah yang dapat menyebabkan dampak yang negatif bagi lingkungan. Limbah yang dihasilkan dari proses pembakaran batubara tersebut berupa abu dan debu. Abu tersebut ada yang jatuh dan tertinggal atau mengendap di dasar boiler yang disebut abu dasar (bottom ash) dan ada abu yang terbawa oleh gas buang dan keluar melalui cerobong asap boiler disebut dengan abu layang (fly Ash). Abu layang ini merupakan limbah produk samping dari pembakaran batu bara yang akan terakumulasi dan berpengaruh terhadap kenaikan limbah industri global

Berdasarkan kepada Peraturan Pemerintah Nomor 101 tahun 2014 tentang pengelolaan limbah Bahan Berbahaya dan Beracun (B3), abu layang termasuk salah satu jenis limbah B3. Keberadaan limbah abu layang batubara jika diproduksi secara besar-besaran oleh industri, hal ini akan berdampak terhadap lingkungan. Oleh sebab itu, perlu adanya upaya pengelolaan atau pengendalian dari dampak yang dihasilkan dari industri penghasil limbah abu layang ini, yaitu dengan cara memanfaatkan kembali limbah abu layang ini menjadi sesuatu yang berguna.

Pemanfaatan limbah Bahan Berbahaya dan Beracun (B3) adalah kegiatan memanfaatkan kembali, atau mendaur ulang limbah B3 menjadi produk yang bermanfaat yang aman bagi kesehatan manusia dan lingkungan hidup, selain itu juga dapat mengurangi keberadaan jumlah limbah B3 di lingkungan yang dihasilkan dari industri. Jika dibiarkan di udara bebas selain dapat mencemari lingkungan, akan membahayakan kesehatan manusia khususnya pada sistem pernafasan. Abu layang dapat dimanfaatkan untuk bahan baku semen, beton, batu bata dan pembuatan zeolit. Sebagai upaya untuk menanggulangi dampak negatif dari hasil pembakaran batubara pada pembangkit tenaga listrik yaitu limbah abu layang, maka penelitian ini akan mencoba memanfaatkan limbah abu layang sebagai bahan dasar untuk pembuatan zeolit.

Kandungan yang terdapat dalam abu layang diantaranya yaitu silika $\left(\mathrm{SiO}_{2}\right)$, alumina $\left(\mathrm{Al}_{2} \mathrm{O}_{3}\right)$, dan oksida besi $\left(\mathrm{Fe}_{2} \mathrm{O}_{3}\right)$. Kandungan abu layang komposisinya sama dengan zeolit, sehingga abu layang jika mendapat perlakuan dengan larutan basa dan menggunakan metode hidrotermal akan dapat diubah menjadi zeolit [1]. Mineral alumina dan silika yang terdapat dalam abu layang merupakan bahan dasar untuk pembuatan zeolit. Berdasarkan penelitian yang dilakukan oleh Molina dan Poole [2], tahun 2004 abu layang mengandung $\mathrm{SiO}_{2}$ sekitar $44,53 \%$ dan $\mathrm{Al}_{2} \mathrm{O}_{3}$ sekitar 27,05\%, dengan adanya kandungan $\mathrm{SiO}_{2}$ dan $\mathrm{Al}_{2} \mathrm{O}_{3}$ yang tinggi ini sehingga abu layang bisa dimanfaatkan untuk sintesis zeolit.

Zat-zat anorganik dapat dihilangkan dengan menggunakan asam $\mathrm{H}_{2} \mathrm{SO}_{4}, \mathrm{HNO}_{3}$, dan $\mathrm{HCl}$. Zat anorganik yang terdapat pada abu layang harus dihilangkan karena kontaminan oksida logam terutama $\mathrm{Fe}_{2} \mathrm{O}_{3}, \mathrm{CaO}$ dan $\mathrm{MgO}$ yang terdapat dalam abu layang akan mempengaruhi tingkat kemurnian sintesis zeolit yang terbentuk. Jika pemisahan logam yang terdapat pada abu layang dilakukan menggunakan $\mathrm{H}_{2} \mathrm{SO}_{4}$ jumlah logam yang hilang lebih sedikit jika dibandingkan dengan menggunakan $\mathrm{HCl}$ dan $\mathrm{HNO}_{3}$, hal ini disebabkan karena logam yang dihasilkan tidak mudah larut dalam air sehingga penggunaan $\mathrm{H}_{2} \mathrm{SO}_{4}$ tidak cocok untuk menghilangkan beberapa jenis logam [3]. Sedangkan jika menggunakan $\mathrm{HNO}_{3}$ hanya dapat menghilangkan logam besi saja tetapi logam yang lain tidak dapat dihilangkan. Berdasarkan hasil penelitian yang sudah dilakukan oleh dengan penggunaan variasi asam $\left(\mathrm{H}_{2} \mathrm{SO}_{4}, \mathrm{HCl}, \mathrm{HNO}_{3}\right)$, menunjukkan penggunaan $\mathrm{HCl}$ adalah asam yang paling efektif dalam menghilangkan logam[4]. Berdasarkan hasil penelitian Adjiantoro et al, pada tahun 2010 menunjukkan bahwa pemurnian silikon metalurgi (MG-Si) dengan menggunakan pelarut asam untuk menghilangkan atau menurunkan kandungan pengotor seperti $\mathrm{Fe}, \mathrm{Ca}, \mathrm{Ti}$ dan $\mathrm{Mg}$, larutan asam yang paling efektif adalah $\mathrm{HCl}$ $(70,22 \%)$ dan $\mathrm{HNO}_{3}(55,11 \%)$ [5]. Selain itu pada penelitian yang dilakukan oleh Pratomo et al [6] didapatkan kadar silika tertinggi sebesar 97,30\% dengan menggunakan pelarut $\mathrm{HCl}$ pada sampel abu sekam padi. Demikian juga penelitian yang dilakukan oleh Kurniati [7], menggunakan sampel abu layang dengan pelarut $\mathrm{HCl}$ didapatkan total efisiensi ekstraksi silika sebesar $89 \%$. Sedang penelitian yang dilakukan oleh Aphane et al [8], menggunakan sampel abu layang dengan pelarut $\mathrm{H}_{2} \mathrm{SO}_{4}$, total efisiensi ekstraksi Si hanya sebesar 8\%. Pembentukan zeolit A yang disebabkan oleh kontaminan oksida logam, terutama $\mathrm{Fe}_{2} \mathrm{O}_{3}, \mathrm{CaO}$, dan $\mathrm{MgO}$ dapat dihilangkan dari abu layang 
dengan pemisahan magnetik atau dengan menggunakan asam klorida $(\mathrm{HCl})$ [9].

Abu layang yang digunakan dalam sintesis zeolit dapat diekstrak melalui proses peleburan secara langsung. Adanya pengotor pada abu layang seperti $\mathrm{Fe}$ dan $\mathrm{Ca}$ yang juga ikut larut dalam ekstrak tersebut mengakibatkan zeolit yang terbentuk tingkat kemurniannya rendah. Pengotor $\mathrm{Fe}$ dan Ca yang ikut terlarut dalam ekstrak tersebut mengakibatkan terbentuknya fasa lain sehingga dapat berpengaruh dalam pembentukan kristal zeolit. Pada penelitian yang dilakukan oleh Kurniawan [10]. menggunakan sampel abu dasar dengan pelarut $\mathrm{HCl}$ dengan konsentrasi $12 \mathrm{M}$, didapatkan kandungan besi $(\mathrm{Fe})$ berkurang menjadi 23,50 \%, dan kalsium (Ca) menjadi $11,10 \%$ dan hasil kristalinitas yang diperoleh pada sintesis zeolit A dengan pemisahan Fe dan Ca dari abu dasar pada penelitian sebelumnya sebesar $88,64 \%$ [10]. Berdasarkan penelitian tersebut pemisahan $\mathrm{Fe}$ dan $\mathrm{Ca}$ menggunakan $\mathrm{HCl}$ dari abu dasar atau abu layang dapat dilakukan [10]. Akan tetapi, penelitian tersebut hanya menggunakan satu variasi konsentrasi $\mathrm{HCl}$ saja sehingga masih perlu dilakukan penelitian lebih lanjut menggunakan variasi konsentrasi $\mathrm{HCl}$ untuk mempelajari pengaruh konsentrasi $\mathrm{HCl}$ terhadap pemisahan logam dari abu layang batubara yang akan digunakan sebagai bahan dasar sintesis zeolit dan melihat pengaruhnya terhadap kristalinitas zeolit sintesis yang dihasilkan, dengan harapan diperoleh tingkat kemurnian zeolit yang lebih tinggi lagi.

\section{Metode Penelitian/ Method}

\subsection{Alat dan Bahan}

Alat yang digunakan dalam penelitian ini adalah X-Ray Fluoerescence (XRF). Bahan yang digunakan adalah abu layang batubara, dan asam klorida $(\mathrm{HCl})$.

\subsection{Prosedur Penelitian}

\subsubsection{Identifikasi Komposisi Kimia Abu Layang}

Abu layang terlebih dahulu ditumbuk dan digerus menggunakan lumpang dan mortar porselin lalu diayak menggunakan saringan 200 mesh agar ukurannya seragam, kemudian dilakukan uji karakterisasi menggunakan X-Ray Fluoresence (XRF) untuk menentukan komposisi unsur-unsur kimia dari abu layang.

\subsubsection{Pemisahan Fe dan Ca dari Abu layang}

Sampel abu layang ditumbuk dan digerus menggunakan lumpang dan mortar porselin lalu diayak menggunakan saringan 200 mesh agar ukurannya seragam. Untuk menghilangkan kandungan air yang terdapat pada abu layang, dilakukan pemanasan abu layang di dalam oven pada temperatur $110^{\circ} \mathrm{C}$ selama 3 jam

Pemisahan $\mathrm{Fe}$ dan $\mathrm{Ca}$ dari abu layang ini dilakukan menggunakan larutan $\mathrm{HCl}$ dengan metode refluks. Abu layang ditimbang sebesar 25 gram lalu dimasukkan ke dalam larutan $\mathrm{HCl}$ dengan variasi konsentrasi $12 \mathrm{M}, 15 \mathrm{M}, 18 \mathrm{M}$ sebanyak $200 \mathrm{~mL}$. Selama 4 jam pada suhu $100^{\circ} \mathrm{C}$ campuran diaduk menggunakan pengaduk magnet untuk memaksimalkan proses pemisahan. Campuran dicuci dengan aquades dan disaring lalu dikeringkan di dalam oven pada suhu $105^{\circ} \mathrm{C}$ selama 14 jam. Hasil pemisahan kemudian dikarakterisasi menggunakan X-Ray Fluoresence (XRF) untuk menentukan komposisi unsur-unsur kimia pada abu layang.

\section{$3 \quad$ Hasil dan Diskusi}

Penelitian ini diawali dengan preparasi sampel limbah abu layang yaitu dengan pengayakan dan pengeringan dengan oven. Abu layang di ayak terlebih dahulu dengan menggunakan ayakan 200 mesh. Tujuan pengayakan adalah untuk menyeragamkan ukuran partikel untuk proses sintesis zeolit [11]. Dengan seragamnya ukuran partikel abu layang sebagai bahan dasar sintesis zeolit maka ukuran pori-pori zeolit akan menjadi lebih besar sehingga ketika diaplikasikan menjadi adsorben kemampuan untuk mengadsorpsi menjadi lebih optimal. Selain menyeragamkan ukuran partikel, pengayakan juga bertujuan untuk memperkecil ukuran partikel sehingga unsurunsur logam seperti Fe dan Ca yang terdapat pada abu layang akan lebih cepat proses pelarutannya dalam pelarut $\mathrm{HCl}$. Setelah dilakukan pengayakan dengan ukuran 200 mesh, abu layang dipanaskan di oven pada suhu $110^{\circ} \mathrm{C}$ yang bertujuan untuk menghilangkan kadar air yang terdapat pada abu layang. Selanjutnya dilakukan identifikasi atau menentukan komposisi kimia yang terdapat pada abu layang dengan menggunakan instrumen $X$ Ray Fluoerescence (XRF). Identifikasi komposisi kimia yang terdapat pada abu layang ini sangat penting untuk mengetahui persentasi kandungan $\mathrm{SiO}_{2}$ (Silika) atau $\mathrm{Si}$ (Silikon) dan $\mathrm{Al}_{2} \mathrm{O}_{3}$ (Alumina) atau $\mathrm{Al}$ (Aluminium) yang terdapat dalam abu layang, karena komponen $\mathrm{SiO}_{2}$ dan $\mathrm{Al}_{2} \mathrm{O}_{3}$ adalah komponen utama dalam pembuatan zeolit. Berikut adalah hasil analisa abu layang 
dengan XRF sebelum dilakukan pemisahan dengan $\mathrm{HCl}$ dapat dilihat pada Tabel 1.

Tabel 1. Komposisi Kimia pada Abu Layang sebelum dilakukan Pemisahan dengan $\mathrm{HCl}$

\begin{tabular}{ll}
\hline Unsur & Konsentrasi (\%) \\
\hline $\mathrm{Al}$ & 10,70 \\
$\mathrm{Si}$ & 25,47 \\
$\mathrm{P}$ & 0,52 \\
$\mathrm{Cl}$ & 0,45 \\
$\mathrm{~K}$ & 3,69 \\
$\mathrm{Ca}$ & 21,60 \\
$\mathrm{Ti}$ & 2,15 \\
$\mathrm{Fe}$ & 34,29 \\
$\mathrm{Zr}$ & 0,22 \\
$\mathrm{Ag}$ & 0,55 \\
$\mathrm{Ba}$ & 0,36 \\
\hline Total & $\mathbf{1 0 0 , 0 0}$ \\
\hline $\mathrm{Senyawa}_{\mathrm{Al}} \mathrm{O}_{3}$ & Konsentrasi $(\boldsymbol{\%})$ \\
$\mathrm{SiO}$ & 14,29 \\
$\mathrm{P}_{2} \mathrm{O}_{5}$ & 36,88 \\
$\mathrm{Cl}$ & 0,77 \\
$\mathrm{~K}_{2} \mathrm{O}$ & 0,28 \\
$\mathrm{CaO}_{\mathrm{TiO}}$ & 2,69 \\
$\mathrm{Fe}_{2} \mathrm{O}_{3}$ & 17,62 \\
$\mathrm{ZrO}_{2}$ & 1,97 \\
$\mathrm{Ag}_{2} \mathrm{O}$ & 24,88 \\
$\mathrm{BaO}_{\text {Total }}$ & 0,14 \\
\hline
\end{tabular}

Berdasarkan hasil analisis XRF yang didapat pada Tabel 1, dapat dilihat bahwa kandungan yang terdapat pada abu layang terdapat $\mathrm{Si}$ (silicon) sebesar $25,47 \%$ atau $\mathrm{SiO}_{2}$ sebesar $36,88 \%$ dan $\mathrm{Al}$ (Aluminium) sebesar 10,70\% atau $\mathrm{Al}_{2} \mathrm{O}_{3}$ sebesar $14,29 \%$. Dengan adanya kandungan Silika dan aluminium pada abu layang maka abu layang berpotensi untuk dijadikan sebagai bahan dasar dalam pembuatan zeolit. Banyaknya kandungan Silika dan Alumina dapat digunakan dalam menentukan rasio $\mathrm{Si} / \mathrm{Al}$ yang dapat berpengaruh terhadap jenis zeolit yang terbentuk. Bila dilihat pada Tabel 1 nilai rasio Si/Al pada abu layang tersebut adalah 2,4. Karena nilai rasio $\mathrm{Si} / \mathrm{Al}$ yang dihasilkan termasuk relatif rendah, sehingga abu layang ini dapat digunakan sebagai bahan dasar dalam pembuatan zeolit dengan kadar Si yang rendah contohnya untuk pembuatan zeolit A. Berdasarkan hasil analisa XRF, selain adanya kandungan Si dan Al dalam abu layang, terdapat juga kandungan logam $\mathrm{Fe}$ dan $\mathrm{Ca}$ yang cukup tinggi yaitu sebesar 34,29\% untuk Fe dan 21,60\% untuk $\mathrm{Ca}$. Adanya kandungan $\mathrm{Fe}$ dan $\mathrm{Ca}$ ini dapat mengganggu dalam proses pembuatan zeolit, sehingga kandungan $\mathrm{Fe}$ dan $\mathrm{Ca}$ harus dilakukan pemisahan terlebih dahulu. Pemisahan kandungan $\mathrm{Fe}$ dan $\mathrm{Ca}$ dalam abu layang dilakukan menggunakan asam klorida $(\mathrm{HCl})$ dengan metode refluks. Selama reaksi pemisahan dengan $\mathrm{HCl}, \mathrm{Ca}$ akan bereaksi dengan $\mathrm{HCl}$ membentuk $\mathrm{CaCl}_{2}$ dan $\mathrm{Fe}$ akan bereaksi dengan $\mathrm{HCl}$ membentuk $\mathrm{FeCl}_{3}$, sedangkan siilika $\left(\mathrm{SiO}_{2}\right)$ yang merupakan unsur utama dalam sintesis zeolit tidak bereaksi dengan $\mathrm{HCl}$, reaksinya bisa dilihat seperti pada pers. (1):

$$
\begin{aligned}
\mathrm{M}_{\mathrm{x}} \mathrm{O}_{(\mathrm{s})}, \mathrm{SiO}_{2(\mathrm{~s})}+\mathrm{HCl}_{(\mathrm{aq})} \rightarrow & \mathrm{MCl}_{\mathrm{x}(\mathrm{aq})}+\mathrm{SiO}_{2(\mathrm{~s})}+ \\
& \mathrm{H}_{2} \mathrm{O}_{(\mathrm{l})} \\
& (\text { persamaan 1) }
\end{aligned}
$$

Hasil pemisahan dengan $\mathrm{HCl}$, kemudian dilakukan analisa kembali menggunakan XRF untuk mengetahui seberapa banyak kandungan Fe dan $\mathrm{Ca}$ yang hilang atau berkurang setelah dilakukan pemisahan dengan $\mathrm{HCl}$. Pemisahan kandungan $\mathrm{Fe}$ dan $\mathrm{Ca}$ dilakukan dengan $\mathrm{HCl}$ dengan variasi konsentrasi yaitu $4 \mathrm{M}, 8 \mathrm{M}$, dan 12 M. Dari variasi konsentrasi $\mathrm{HCl}$ ini dapat diketahui pengaruhnya terhadap penghilangan kandungan logam $\mathrm{Fe}$ dan $\mathrm{Ca}$ dalam abu layang. Hasil Analisa XRF tersebut dapat dilihat pada Tabel 2, Tabel 3, dan Tabel 4. 
Tabel 2. Komposisi Kimia Abu Layang sebelum dan setelah dilakukan Pemisahan dengan HCl 4 M

\begin{tabular}{cccccc}
\hline Unsur & $\begin{array}{c}\text { Konsentrasi } \\
\text { sebelum } \\
\text { pemisahan } \\
(\%)\end{array}$ & $\begin{array}{c}\text { Konsentrasi } \\
\text { setelah } \\
\text { pemisahan } \\
(\boldsymbol{\%})\end{array}$ & Senyawa & $\begin{array}{c}\text { Konsentrasi } \\
\text { sebelum } \\
\text { pemisahan } \\
(\boldsymbol{\%})\end{array}$ & $\begin{array}{c}\text { Konsentrasi } \\
\text { setelah } \\
\text { pemisahan } \\
(\boldsymbol{\%})\end{array}$ \\
\hline $\mathrm{Al}$ & 10,70 & 7,68 & $\mathrm{Al}_{2} \mathrm{O}_{3}$ & 14,29 & 9,17 \\
$\mathrm{Si}$ & 25,47 & 60,54 & $\mathrm{SiO}_{2}$ & 36,88 & 72,89 \\
$\mathrm{P}$ & 0,52 & 0,90 & $\mathrm{P}_{2} \mathrm{O}_{5}$ & 0,77 & 0,97 \\
$\mathrm{Cl}$ & 0,45 & 0,93 & $\mathrm{Cl}$ & 0,28 & 0,43 \\
$\mathrm{~K}$ & 3,69 & 5,78 & $\mathrm{~K}_{2} \mathrm{O}$ & 2,69 & 3,11 \\
$\mathrm{Ca}$ & 21,60 & 3,59 & $\mathrm{CaO}$ & 17,62 & 2,14 \\
$\mathrm{Ti}$ & 2,15 & 3,08 & $\mathrm{TiO}_{2}$ & 1,97 & 2,11 \\
$\mathrm{Fe}$ & 34,29 & 16,29 & $\mathrm{Fe}_{2} \mathrm{O}_{3}$ & 24,88 & 8,69 \\
$\mathrm{Zr}$ & 0,22 & 0,36 & $\mathrm{ZrO}_{2}$ & 0,14 & 0,16 \\
$\mathrm{Ag}$ & 0,55 & 0,51 & $\mathrm{Ag}_{2} \mathrm{O}$ & 0,28 & 0,19 \\
$\mathrm{Ba}$ & 0,36 & 0,36 & $\mathrm{BaO}$ & 0,20 & 0,15 \\
\hline Total & $\mathbf{1 0 0 , 0 0}$ & $\mathbf{1 0 0 , 0 0}$ & $\mathbf{T o t a l}$ & $\mathbf{1 0 0 , 0 0}$ & $\mathbf{1 0 0 , 0 0}$ \\
\hline
\end{tabular}

Tabel 3. Komposisi Kimia Abu Layang sebelum dan setelah dilakukan Pemisahan dengan $\mathrm{HCl} 8 \mathrm{M}$

\begin{tabular}{|c|c|c|c|c|c|}
\hline Unsur & $\begin{array}{c}\text { Konsentrasi } \\
\text { sebelum } \\
\text { pemisahan } \\
(\%)\end{array}$ & $\begin{array}{c}\text { Konsentrasi } \\
\text { setelah } \\
\text { pemisahan } \\
(\%)\end{array}$ & Senyawa & $\begin{array}{c}\text { Konsentrasi } \\
\text { sebelum } \\
\text { pemisahan } \\
(\%)\end{array}$ & $\begin{array}{c}\text { Konsentrasi } \\
\text { setelah } \\
\text { pemisahan } \\
(\%)\end{array}$ \\
\hline $\mathrm{Al}$ & 10,70 & 6,49 & $\mathrm{Al}_{2} \mathrm{O}_{3}$ & 14,29 & 7,72 \\
\hline $\mathrm{Si}$ & 25,47 & 63,69 & $\mathrm{SiO}_{2}$ & 36,88 & 75,87 \\
\hline $\mathrm{P}$ & 0,52 & 0,97 & $\mathrm{P}_{2} \mathrm{O}_{5}$ & 0,77 & 1,01 \\
\hline $\mathrm{Cl}$ & 0,45 & 1,33 & $\mathrm{Cl}$ & 0,28 & 0,59 \\
\hline $\mathrm{K}$ & 3,69 & 5,48 & $\mathrm{~K}_{2} \mathrm{O}$ & 2,69 & 2,87 \\
\hline $\mathrm{Ca}$ & 21,60 & 3,30 & $\mathrm{CaO}$ & 17,62 & 1,92 \\
\hline $\mathrm{Ti}$ & 2,15 & 3,13 & $\mathrm{TiO}_{2}$ & 1,97 & 2,09 \\
\hline $\mathrm{Fe}$ & 34,29 & 14,03 & $\mathrm{Fe}_{2} \mathrm{O}_{3}$ & 24,88 & 7,31 \\
\hline $\mathrm{Zr}$ & 0,22 & 0,37 & $\mathrm{ZrO}_{2}$ & 0,14 & 0,17 \\
\hline $\mathrm{Ag}$ & 0,55 & 0,62 & $\mathrm{Ag}_{2} \mathrm{O}$ & 0,28 & 0,23 \\
\hline $\mathrm{Ba}$ & 0,36 & 0,43 & $\mathrm{BaO}$ & 0,20 & 0,17 \\
\hline Total & 100,00 & 0.43 & Total & 100,00 & 100,00 \\
\hline
\end{tabular}


Tabel 4. Komposisi Kimia Abu Layang sebelum dan setelah dilakukan Pemisahan dengan HCl 12 M

\begin{tabular}{|c|c|c|c|c|c|}
\hline Unsur & $\begin{array}{c}\text { Konsentrasi } \\
\text { sebelum } \\
\text { pemisahan } \\
(\%)\end{array}$ & $\begin{array}{c}\text { Konsentrasi } \\
\text { setelah } \\
\text { pemisahan } \\
(\%)\end{array}$ & Senyawa & $\begin{array}{c}\text { Konsentrasi } \\
\text { sebelum } \\
\text { pemisahan } \\
(\%)\end{array}$ & $\begin{array}{c}\text { Konsentrasi } \\
\text { setelah } \\
\text { pemisahan } \\
(\%)\end{array}$ \\
\hline $\mathrm{Al}$ & 10,70 & 6,60 & $\mathrm{Al}_{2} \mathrm{O}_{3}$ & 14,29 & 7,81 \\
\hline $\mathrm{Si}$ & 25,47 & 67,21 & $\mathrm{SiO}_{2}$ & 36,88 & 78,25 \\
\hline $\mathrm{P}$ & 0,52 & 0,91 & $\mathrm{P}_{2} \mathrm{O}_{5}$ & 0,77 & 0,91 \\
\hline $\mathrm{Cl}$ & 0,45 & 1,44 & $\mathrm{Cl}$ & 0,28 & 0,62 \\
\hline $\mathrm{K}$ & 3,69 & 5,01 & $\mathrm{~K}_{2} \mathrm{O}$ & 2,69 & 2,51 \\
\hline $\mathrm{Ca}$ & 21,60 & 2,96 & $\mathrm{CaO}$ & 17,62 & 1,65 \\
\hline $\mathrm{Ti}$ & 2,15 & 2,82 & $\mathrm{TiO}_{2}$ & 1,97 & 1,81 \\
\hline $\mathrm{Fe}$ & 34,29 & 11,98 & $\mathrm{Fe}_{2} \mathrm{O}_{3}$ & 24,88 & 6,04 \\
\hline $\mathrm{Zr}$ & 0,22 & 0,34 & $\mathrm{ZrO}_{2}$ & 0,14 & 0,15 \\
\hline $\mathrm{Ag}$ & 0,55 & 0,48 & $\mathrm{Ag}_{2} \mathrm{O}$ & 0,28 & 0,17 \\
\hline $\mathrm{Ba}$ & 0,36 & 0,26 & $\mathrm{BaO}$ & 0,20 & 0,10 \\
\hline Total & 100,00 & 100,00 & Total & 100,00 & 100,00 \\
\hline
\end{tabular}

Berdasarkan hasil analisa yang diperoleh menggunakan instrumen XRF terlihat bahwa pada Tabel 2 pemisahan $\mathrm{Fe}$ dan $\mathrm{Ca}$ dari abu layang dengan menggunakan $\mathrm{HCl} 4 \mathrm{M}$ diperoleh kandungan logam Fe sebesar 16,29\% berkurang $18 \%$ dan Ca sebesar 3,59\% berkurang $18,01 \%$ dari sebelum dilakukan pemisahan dengan menggunakan $\mathrm{HCl}$. Tabel 3 pemisahan $\mathrm{Fe}$ dan $\mathrm{Ca}$ dari abu layang dengan menggunakan $\mathrm{HCl} 8 \mathrm{M}$ diperoleh kandungan logam $\mathrm{Fe}$ sebesar 14,03\% berkurang 20,26\% dan $\mathrm{Ca}$ sebesar 3,30\% berkurang $18,3 \%$ dari sebelum dilakukan pemisahan menggunakan $\mathrm{HCl}$. Sedangkan pada Tabel 4 pemisahan $\mathrm{Fe}$ dan $\mathrm{Ca}$ dari abu layang menggunakan $\mathrm{HCl} 12 \mathrm{M}$ diperoleh kandungan logam Fe sebesar 11,98\% berkurang 22,31\% dan Ca sebesar 2,96\% berkurang 18,64\% dari keadaan sebelum dilakukan pemisahan dengan menggunakan $\mathrm{HCl}$. Pengaruh konsentrasi $\mathrm{HCl}$ terhadap penghilangan logam $\mathrm{Fe}$ dan $\mathrm{Ca}$ dapat dilihat pada Gambar 1.

Dari hasil Gambar 1 terlihat bahwa pemisahan kandungan logam $\mathrm{Fe}$ dan $\mathrm{Ca}$ dari abu layang dengan menggunakan $\mathrm{HCl}$ semakin berkurang dengan semakin besarnya konsentrasi $\mathrm{HCl}$. Hal ini disebabkan karena semakin besar konsentrasi, maka semakin banyak $\mathrm{Fe}$ dan $\mathrm{Ca}$ yang terikat bereaksi dengan $\mathrm{HCl}$ dimana $\mathrm{Ca}$ akan bereaksi dengan $\mathrm{HCl}$ membentuk $\mathrm{CaCl}_{2}$ dan $\mathrm{Fe}$ akan bereaksi dengan $\mathrm{HCl}$ membentuk $\mathrm{FeCl}_{3}$ sehingga kadar $\mathrm{Fe}$ dan $\mathrm{Ca}$ dalam abu layang semakin berkurang dengan semakin besarnya konsentrasi $\mathrm{HCl}$. Berikut reaksi yang terjadi dalam proses pemisahan logam-logam oksida yang terdapat pada abu layang ketika direaksikan dengan $\mathrm{HCl}$ yang dapat dilihat pada persamaan (24) (10)

$$
\begin{array}{r}
\mathrm{CaCO}_{3(\mathrm{~s})}+2 \mathrm{HCl}_{(\mathrm{aq})} \rightarrow \mathrm{CaCl}_{2(\mathrm{aq})}+\underset{(\text { persamaan 2) }}{\mathrm{CO}_{2(\mathrm{~g})}+\mathrm{H}_{2} \mathrm{O}_{(\mathrm{l})}} \\
\mathrm{CaO}_{(\mathrm{s})}+2 \mathrm{HCl}_{(\mathrm{aq})} \rightarrow \mathrm{CaCl}_{2(\mathrm{aq})}+\mathrm{H}_{2} \mathrm{O}_{(\mathrm{l})} \\
(\text { persamaan 3) }
\end{array}
$$

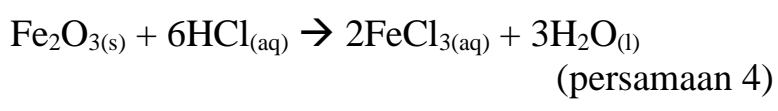

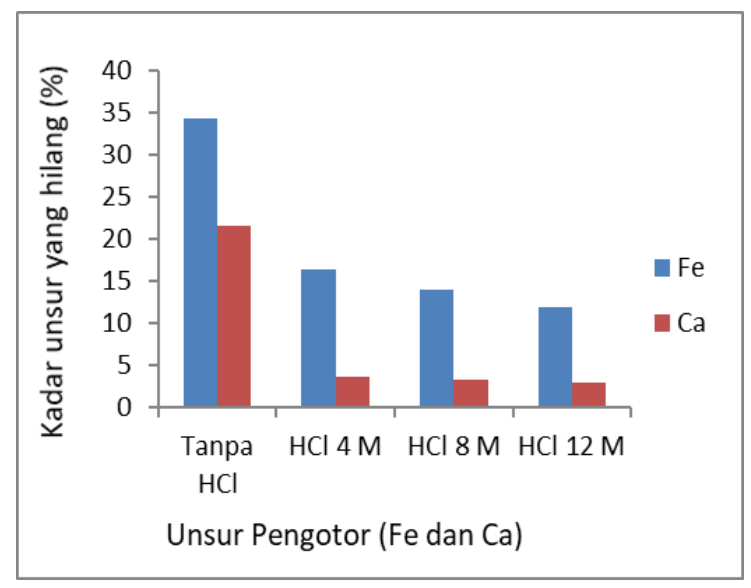

Gambar 1. Pengaruh Konsentrasi $\mathrm{HCl}$ terhadap penghilangan logam $\mathrm{Fe}$ dan $\mathrm{C}$

Jika dilihat dari reaksi di atas, menunjukkan bahwa $\mathrm{Ca}$ dalam bentuk fasa kalsit $\left(\mathrm{CaCO}_{3}\right)$ dan dalam bentuk senyawa kalsium oksida $(\mathrm{CaO})$ dapat bereaksi dengan $\mathrm{HCl}$ membentuk $\mathrm{CaCl}_{2}$ yang dapat larut di dalam air, sedangkan Fe dalam 
bentuk senyawa $\mathrm{Fe}_{2} \mathrm{O}_{3}$ akan bereaksi dengan $\mathrm{HCl}$ membentuk $\mathrm{FeCl}_{3}$ yang juga mudah larut dalam air. Selama proses pencucian abu layang dengan metode refluks menggunakan larutan $\mathrm{HCl}$ kandungan senyawa pengotor logam $\mathrm{Fe}$ dan $\mathrm{Ca}$ akan larut dalam $\mathrm{HCl}$, sehingga kandungannya akan berkurang pada abu layang.

Pada penelitian yang dilakukan oleh Anggia et al [12] didapatkan bahwa semakin tinggi konsentrasi $\mathrm{HCl}$ yaitu $1 \mathrm{M}, 2 \mathrm{M}$ dan $4 \mathrm{M}$ maka pelarutan logam $\mathrm{Fe}$ dan $\mathrm{Ca}$ dari abu layang akan semakin meningkat, untuk $\mathrm{Fe}$ dihasilkan dari $7,47 \%$ menjadi $8,13 \%$ sedangkan untuk $\mathrm{Ca}$ dihasilkan dari $1,91 \%$ menjadi $3,26 \%$. Berdasarkan teori, semakin besar konsentrasi asam maka logam yang dapat larut akan semakin banyak, hal ini disebabkan karena ion $\mathrm{H}^{+}$yang berasal dari $\mathrm{HCl}$ akan semakin banyak juga yang terdifusi, akibatnya logam $\mathrm{Fe}$ dan $\mathrm{Ca}$ pada abu layang akan bereaksi dengan ion $\mathrm{Cl}^{-}$membentuk $\mathrm{FeCl}_{3}$ dan $\mathrm{CaCl}_{2}$ [13]. Sedangkan pada penelitian Kurniawan, et al, tahun 2017 didapatkan penggunaan $\mathrm{HCl} 12 \mathrm{M}$ mampu mengurangi kandungan logam $\mathrm{Fe}$ dan $\mathrm{Ca}$ dari abu dasar sebesar 25,90\% untuk Fe dan 14,40\% untuk logam $\mathrm{Ca}$, hasil pemisahan $\mathrm{Fe}$ dan $\mathrm{Ca}$ dari abu dasar tersebut dapat meningkatkan kristalinitas pada proses sintesis zeolit A sebanyak 88,64\% [10].

Selain itu kemurnian silika akan didapat pada saat pencucian abu layang menggunakan $\mathrm{HCl}$ dengan konsentrasi asam paling tinggi, hal ini dikarenakan jumlah pengotor yang hilang akan semakin banyak. Pada penelitian ini pemisahan $\mathrm{Fe}$ dan $\mathrm{Ca}$ dari abu layang menggunakan $\mathrm{HCl}$ dengan konsentrasi $12 \mathrm{M}$ diperoleh kandungan silika sebesar 78,25\% dengan kadar yang paling murni dibandingkan dengan menggunakan $\mathrm{HCl} 4 \mathrm{M}$ kandungan silikanya sebesar $72,89 \%$ dan $75,87 \%$ dengan $\mathrm{HCl} 8 \mathrm{M}$, hal ini disebabkan karena kandungan unsur-unsur yang dianggap penganggu yaitu Fe dan Ca semakin banyak yang larut dalam pelarut $\mathrm{HCl}$ pada konsentrasi $12 \mathrm{M}$, sedangkan silika tidak dapat larut [14]. Dengan hilangnya atau berkurangnya logam pengotor $\mathrm{Fe}$ dan $\mathrm{Ca}$ maka untuk proses sintesis zeolit diharapkan akan meningkatkan kristanilitas zeolit sehingga kemampuan kinerjanya sebagai adsorben akan meningkat.

\section{Kesimpulan}

Berdasarkan hasil yang diperoleh dari instrumen X-Ray Fluorescence (XRF) pada abu layang batubara sebelum dilakukan pemisahan dengan pelarut $\mathrm{HCl}$ didapatkan logam $\mathrm{Fe}$ sebesar $34,29 \%$ dan Ca sebesar 21,60\% . Sedangkan hasil
XRF pada abu layang setelah dilakukan pemisahan dengan $\mathrm{HCl} 4 \mathrm{M}, 8 \mathrm{M}$ dan $12 \mathrm{M}$ berturut-turut diperoleh kandungan logam $\mathrm{Fe}$ sebesar 16,29\%; 14,03\%; 11,98\% dan Ca sebesar $3,59 \%, 3,30 \%$, dan $2,96 \%$. Sehingga dapat disimpulkan bahwa pemisahan kandungan logam Fe dan Ca kadarnya semakin berkurang dari abu layang dengan semakin besar konsentrasi $\mathrm{HCl}$.

\section{Ucapan Terima Kasih}

Penulis menyampaikan ucapan terima kasih kepada Bapak Mahmud selaku laboran dan semua pihak yang telah banyak membantu dalam penelitian ini yang tidak dapat disebutkan satu per satu.

\section{Daftar Pustaka}

[1]. Tanaka H, Sakai Y, Hino R. Formation of Na-A and -X zeolites from waste solutions in conversion of coal fly ash to zeolites. Mater Res Bull [Internet]. 2002;37(11):1873-84. Available from: http://dx.doi.org/10.1016/s00255408(02)00861-9

[2]. Molina A, Poole C. A Comparative Study using Two Methods to Produce Zeolites from Fly Ash. Miner Eng [Internet]. 2004;17(2):167-73. Available from: http://dx.doi.org/10.1016/j.mineng.2003.10 .025

[3]. Hidayah SR. Sintesis dan Karakterisasi Nanozeolit Y dari Abu Sekam Padi dengan Variasi Rasio SiO2/A12O3 menggunakan Templat Organik. Universitas Islam Negeri Maulana Malik Ibrahim; 2016.

[4]. Chakraverty A, Mishra P, Banerjee HD. Investigation of combustion of raw and acid-leached rice husk for production of pure amorphous white silica. J Mater Sci [Internet]. 1988;23(1):21-4. Available from:

http://dx.doi.org/10.1007/bf01174029

[5]. Adjiantoro B, Mabruri E. Pengaruh Waktu Pelindian pada Proses Pemurnian Silikon Tingkat Metalurgi Menggunakan Larutan HCl[Effect of Leaching Time on Purification Process of Metallurgical Grade Silicon by Using Acid Solution]. Metalurgi [Internet]. 2016;27(1):1. Available from: http://dx.doi.org/10.14203/metalurgi.v27i1 .133 
[6]. Pratomo I, Wardhani S, Purwonugroho D. Pengaruh Teknik Ekstraksi dan Konsentrasi $\mathrm{HCl}$ dalam Ekstraksi Silika dari Sekam Padi untuk Sintesis Silika Xerogel. J Ilmu Kim Univ Brawijaya. 2013;2(1):358-64.

[7]. Kurniati E. Ekstraksi Silica White Powder dariLlimbah Padat Pembangkit Listrik Tenaga Panas Bumi. Surabaya: UPN Press; 2009.

[8]. Aphane ME, Van der Merwe EM, Doucet FJ, Petrik L. Aphane ME, Van Der Merwe EM, Doucet FJ, Petrik L. The effect of sulphuric acid concentration on the removal of reactive aluminium from south african coal fly ash. In: World of Coal Fly Ash (WOCA) Conference. Nasvhille; 2015.

[9]. Chareonpanich M, Jullaphan O, Tang C. Bench-scale Synthesis of Zeolite A from Subbituminous Coal Ashes with High Crystalline Silica Content. J Clean Prod [Internet]. 2011;19(1):58-63. Available from:

http://dx.doi.org/10.1016/j.jclepro.2010.08. 012
[10]. Kurniawan RY, Widiastuti N. Sintesis Zeolit-A dari Abu Dasar Batubara dengan Pemisahan Fe dan Ca. J Sains dan Seni ITS [Internet]. 2017;6(1). Available from: http://dx.doi.org/10.12962/j23373520.v6i1. 22842

[11]. Wicaksono AA. Pengaruh Temperatur pada Proses Bayer terhadap Ekstraksi Alumina pada Bijih Nepheline. Universitas Indonesia; 2012.

[12]. Anggia DM, Suprapto. Pemurnian Silika Pada Abu Layang Dari Pembangkit Listrik di Paiton (PT YTL) Dengan Pelarutan Asam Klorida dan Aqua regia. J Sains Seni ITS. 2016;5(2).

[13]. Fitri NTD. Ekstraksi dan Penentuan Kadar Ion Alumunium Hasil Ekstraksi dari Abu Terbang (Fly Ash) batubara. Universitas Jember; 2014.

[14]. Scherban S, Raizman V, Pevzner I. Technologies of coal fly ash processing into metallurgical and silicate chemical products. Prepr Pap Am Chem Soc Div Fuel Chem. 1995;40(4). 